\title{
Chemico-mobility of Toxic Heavy Metals in Environmental Samples
}

\author{
H. Ileka, C. Hange, F. Hakala, H. Matheus and O. Awofolu
}

\begin{abstract}
The article reports on the occurrences, level, and mobility of selected trace metals in environmental samples. The conceptual basis was to examine possible influence of anthropogenic activities and impact on human and environmental health. Environmental samples (soil, plant, and lower animal) were randomly collected from stratified study/sampling areas, preserved and pre-treated before analysis. Mineral acid digestion procedure was employed for the isolation of metallic contents in samples and elemental qualitative and quantitative analysis was by ICP-OES. Analytical protocol was validated through the quality assurance process and was found acceptable with quantitative metallic recoveries in the range of $85-90 \%$; hence considered applicable for the analyses of environmental samples. The mean concentration of analysed metals in soil samples ranged from 53.2- $2532.8 \mathrm{mg} / \mathrm{kg}$ (Cu); 59.5- $2020.1 \mathrm{mg} / \mathrm{kg}$ (Zn); 1.80 $21.26 \mathrm{mg} / \mathrm{kg}(\mathrm{Cd})$ and $19.6-140.9 \mathrm{mg} / \mathrm{kg}(\mathrm{Pb})$. The mean level in grass samples ranged from $9.33-38.63 \mathrm{mg} / \mathrm{kg}(\mathrm{Cu}) ; 64.20-105.18$ $\mathrm{mg} / \mathrm{kg}(\mathrm{Zn}) ; 0.28-0.73 \mathrm{mg} / \mathrm{kg}(\mathrm{Cd})$ and $0.53-16.26 \mathrm{mg} / \mathrm{kg}(\mathrm{Pb})$ while the mean level in lower animal sample (beetle) varied from 9.6 - $105.3 \mathrm{mg} / \mathrm{kg}(\mathrm{Cu}) ; 134.1-297.2 \mathrm{mg} / \mathrm{kg}(\mathrm{Zn}) ; 0.63$ - 3.78 (Cd) and $8.0-29.1 \mathrm{mg} / \mathrm{kg}(\mathrm{Pb})$ across sample collection points (SCPs) 1-4 respectively. Metallic transfer factors (TFs) were in the order $\mathrm{Zn}>\mathrm{Cd}>\mathrm{Cu}>\mathrm{Pb}$ with metal Pollution Indices (MPIs) in the order SCP1 > SCP2 > SCP3 > SCP4. About 60-70 \% of analysed metals were above the maximum allowable limits (MALs) in soil and plant samples. Results obtained revealed general prevalence of analysed metals at all sampled sites with indication of metallic mobility across the food chain which portrayed dire consequences for environmental and human health. Systematic environmental remediation and pollution abatement strategies are recommended.
\end{abstract}

Key words: Human health, Heavy metals, Incidences, Pollution

\section{INTRODUCTION}

Although, heavy metals are known to be natural constituents of the earth's crust [1], their levels have increased threateningly over the decades at an unprecedented rate due to anthropogenic activities $[2,3]$. Potential activities with propensity to increase environmental burden of heavy metals include petrochemical industries [4], mining operations [5] and agriculture [6]. Hence, the prevalence of toxic heavy metals such as $\mathrm{Cd}, \mathrm{As}, \mathrm{Pb}, \mathrm{Zn}, \mathrm{Cu}$, and others in the ecosystems at elevated levels continues to be of great concern in view of their health implications. In addition, toxic metals such as cadmium (Cd) and arsenic (As) are of

O. Awofolu is a lecturer in the Department of Health Sciences, Faculty of Health and Applied Sciences, NUST. His e-mail address is: oawofolu@nust.na. Other authors were final year students of the Professional Bachelor of Environmental Health Sciences at the same institution. significance since they have no physiological benefits [7]. Cadmium is a known endocrine disruptor in human [8] while lead $(\mathrm{Pb})$ has been implicated in the disruption of gene expression [9], hence the incessant interest in monitoring the trend and distribution of these metals in the various ecosystems mainly for health purposes.

The general concern about the prevalence of these toxic metals in the environment is exacerbated by their potential for intra- and inter-ecosystem mobility. Soil for example, has been described as a repository of heavy metals [10] and the mobility of heavy metal from soil into water [11] and air [12] has been reported. In addition, certain factors have also been known to influence the distribution of these metals in soil. Factors such as $\mathrm{pH}$ [13], redox potential [14] and soil type [15] are known to influence the level of metals that may be available at a point in time in the substrate. Once the heavy metal is labile, it can be taken up by organisms within the terrestrial (soil) ecosystem and possible transfer into the aquatic ecosystem through erosional process among others. Erosional process of surface soil has been reported to be responsible for the transfer to heavy metals into the aquatic ecosystem [16].

Although, the mobility, bioavailability, and potential impact of heavy metals on human and environmental health have been ascribed to their presence in some chemical forms such as exchangeable and carbonate-bound in soil [17]. These fractions have been speciated through a well-known procedure of sequential extraction $[18,19]$. However, all the mobile fractions of the heavy metals can also be bioavailable depending on the physical properties of the soil [20]. Changes in factors such as $\mathrm{pH}$ of the soil has been reported to influence the bioavailability of heavy metals in soil [21, 22]. In this study however, the interest lies in examining the prevalence of selected heavy metals in soil and possible mobility into indicator organism of lower animal and plant in a mining community.

\section{MATERIALS AND METHODS}

\section{A. Study Area}

The study was conducted within the local municipal township of Tsumeb, located in the Northern part of Namibia close to the Etosha National Park in the Oshikoto Region. The town is at an altitude of 1, $266 \mathrm{~m}$, latitude -19, 2333 (1913'59.880's) and longitude 17, 7167 (1743'0.120' E). It has a population of about 19840 and a total area of $271 \mathrm{~km}^{2}$ [23]. Notable business events within the study area are mining, metal foundry, petrochemical and agriculture. The study area (township) was divided into four sections referred to as sample collection point 
(SCP). Therefore, samples were collected from each section

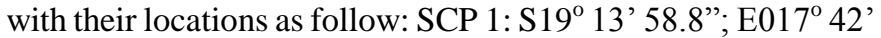

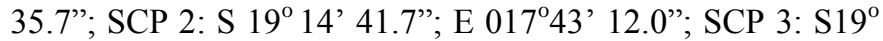
$15^{\prime} 21.6^{\prime \prime} ; \mathrm{E} 017^{\circ} 42^{\prime} 08.5^{\prime \prime}$ and SCP 4: S19 $15^{\prime} 38.5^{\prime \prime} ; \mathrm{E} 017^{\circ}$ 42 ' 43.2"'.

\section{B. Samples and Sampling Process}

In this study, metal indicator samples used were the insect (Stag beetle) and plant together with the soil samples. The plant sample was the African Foxtail grass (Cenchrus ciliaris) which grows wildly and are readily available in the study area, hence considered as good indicator while the invertebrate was the Stag beetle e.g. Rhinotia hemistictus. Samples were collected from the four (4) different sections represented as SCP1-SCP4 as stated earlier between the period of July and October 2016. Soil and plant samples were randomly collected from each section, whereas purposive sampling was used for the invertebrate. This was specifically search for because of availability and collected for analysis.

Soil samples to the depth of about $100 \mathrm{~mm}$ were collected randomly from each site with the aid of clean stainless-steel soil trowel. The trowel was washed and rinsed properly with water after each sampling. Soil and plant samples were placed in transparent plastic zipper bags, labelled, and taken to the laboratory for further treatment and analysis. The invertebrate samples were collected by digging into the soil debris, particularly under large trees and stones within each site, placed in the zipper bags, labelled, and taken to the laboratory for further treatment and analysis.

\section{Sample Treatment and Analysis}

Deposits of soil particles on plant and invertebrate samples were removed by rinsing gently with tap water and then with distilled water. The plants were cut into smaller pieces, placed in the crucible, and dried in oven at $120^{\circ} \mathrm{C}$ for $24 \mathrm{~h}$. The invertebrate samples were also placed in crucibles and dried in a similar manner whereas, soil samples were dried-up at $30^{\circ} \mathrm{C}$. All samples were pulverized using acid washed mortar and pestle and sieved using 0.45 micrometre sieve. Extraction of heavy metal from samples followed a previously described procedure [24], the quality assurance of the analytical protocol was by standard metal addition. Metallic quantification was by Inductively-Coupled Plasma Emission Spectroscopy (ICP-OES).

\section{Statistical Analysis}

Correlation of heavy metal data from each SCP was determined to verify possible relationship amongst them using the MS excel. Heavy metal transfer factor (TF), expressed as the ratio of the level of metal in soil to that of the plant within the SCP was also determined to reveal the accumulation pattern of metals by the plant. The metal pollution indices (MPIs) were determined as the ratio of heavy metal concentration obtained at study site to that from the control site. This is important in order to establish the extent of pollution/contamination of the site. MPI values $>1$ express the extent of pollution of the site while values $<1$ defines the contamination range. The two ranges contain further sub-divisions that indicate the scale of impact as shown in Table 2 below.

\section{RESULTS}

The quality assurance of an experimental process is important to check the applicability of the method for sample analysis. Hence result of this process, represented by percentage metal recoveries from standard metal additions were in the range of $\mathrm{Cd}(78 \pm 0.002) ; \mathrm{Pb}(89 \pm 0.005) ; \mathrm{Cu}(90 \pm$ $0.003)$ and $\mathrm{Zn}(87 \pm 0.01)$.

The quality assured method was then applied to the determination of heavy metals in samples. The mean concentration of heavy metals in soil samples (Fig. 1) for $\mathrm{Cu}$ at SCP1, SCP2, SCP3 and SCP4 were $2533 \mathrm{mg} / \mathrm{kg} ; 134.8 \mathrm{mg} / \mathrm{kg}$; $38.9 \mathrm{mg} / \mathrm{kg}, 53.2 \mathrm{mg} / \mathrm{kg}$ respectively while the value for control site (CS) was $162.2 \mathrm{mg} / \mathrm{kg}$. The value for $\mathrm{Zn}$ varied from $2020.1 \mathrm{mg} / \mathrm{kg} ; 99.7 \mathrm{mg} / \mathrm{kg} ; 59.5 \mathrm{mg} / \mathrm{kg}$ and $66.9 \mathrm{mg} / \mathrm{kg}$ with CS value of $91.4 \mathrm{mg} / \mathrm{kg}$. The mean concentration for $\mathrm{Cd}$ was 21.3 $\mathrm{mg} / \mathrm{kg} ; 4.2 \mathrm{mg} / \mathrm{kg} ; 1.8 \mathrm{mg} / \mathrm{kg}$ and $1.78 \mathrm{mg} / \mathrm{kg}$ with CS value of $5.6 \mathrm{mg} / \mathrm{kg}$. Lastly, the mean concentration of $\mathrm{Pb}$ varied from $140 \mathrm{mg} / \mathrm{kg} ; 62.0 \mathrm{mg} / \mathrm{kg} ; 21.7 \mathrm{mg} / \mathrm{kg}$ and $19.6 \mathrm{mg} / \mathrm{kg}$ also with CS level of $1.20 \mathrm{mg} / \mathrm{kg}$; across sampling period and SCP sequence as above.

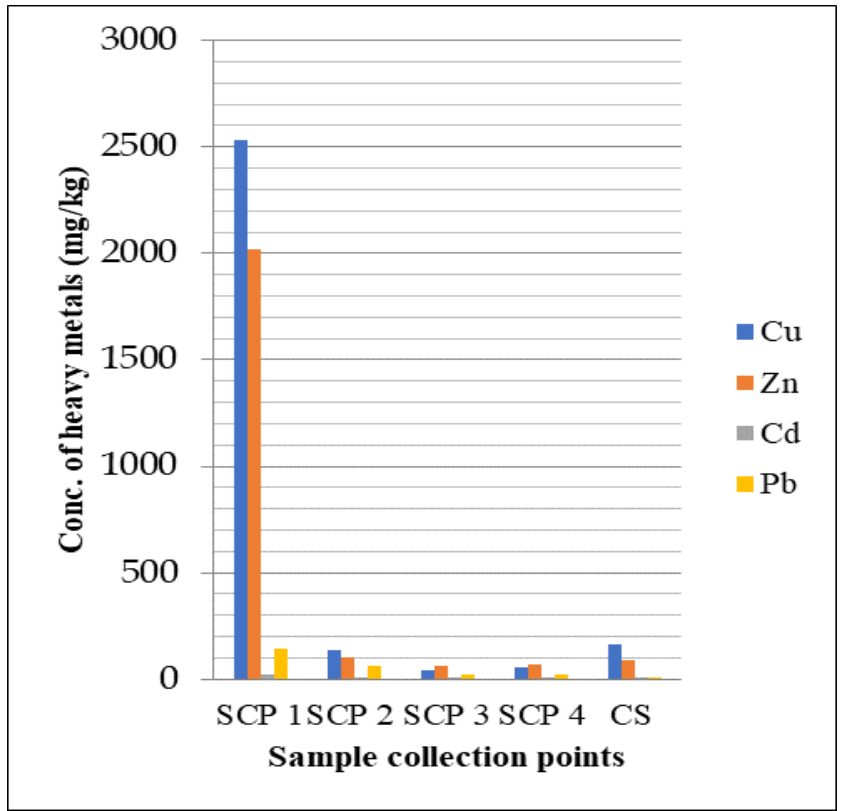

Fig. 1: Mean conc. (mg/kg) of heavy metals in soil samples across the sampling points; $\mathrm{CS}=$ Control Site

The mean concentrations of heavy metals in the African foxtail grass sample (Cenchrus ciliaris) are as presented in fig. 2. The mean values of $\mathrm{Cu}$ ranged from $38.6 \mathrm{mg} / \mathrm{kg} ; 14.7 \mathrm{mg} / \mathrm{kg}$; $12.0 \mathrm{mg} / \mathrm{kg}$ and $9.3 \mathrm{mg} / \mathrm{kg}$ with the CS value of $4.6 \mathrm{mg} / \mathrm{kg}$. The mean concentration of $\mathrm{Zn}$ ranged from $105.2 \mathrm{mg} . \mathrm{kg} ; 74.4$ $\mathrm{mg} / \mathrm{kg} ; 69.1 \mathrm{mg} / \mathrm{kg}$ and $64.2 \mathrm{mg} / \mathrm{kg}$ with CS mean value of 31.7 $\mathrm{mg} / \mathrm{kg}$. The mean level of Cd was $0.73 \mathrm{mg} / \mathrm{kg} ; 0.45 \mathrm{mg} / \mathrm{kg} ; 0.28$ $\mathrm{mg} / \mathrm{kg}$ and $3.0 \mathrm{mg} / \mathrm{kg}$ with CS value of $0.05 \mathrm{mg} / \mathrm{kg}$ while the mean level for $\mathrm{Pb}$ varied from $16.3 \mathrm{mg} / \mathrm{kg} ; 3.2 \mathrm{mg} / \mathrm{kg} ; 2.12$ $\mathrm{mg} / \mathrm{kg}$ and $0.53 \mathrm{mg} / \mathrm{kg}$ also with CS value of $0.05 \mathrm{mg} / \mathrm{kg}$; all respectively at SCP1, SCP2, SCP3 and SCP4 across the sampling periods. 


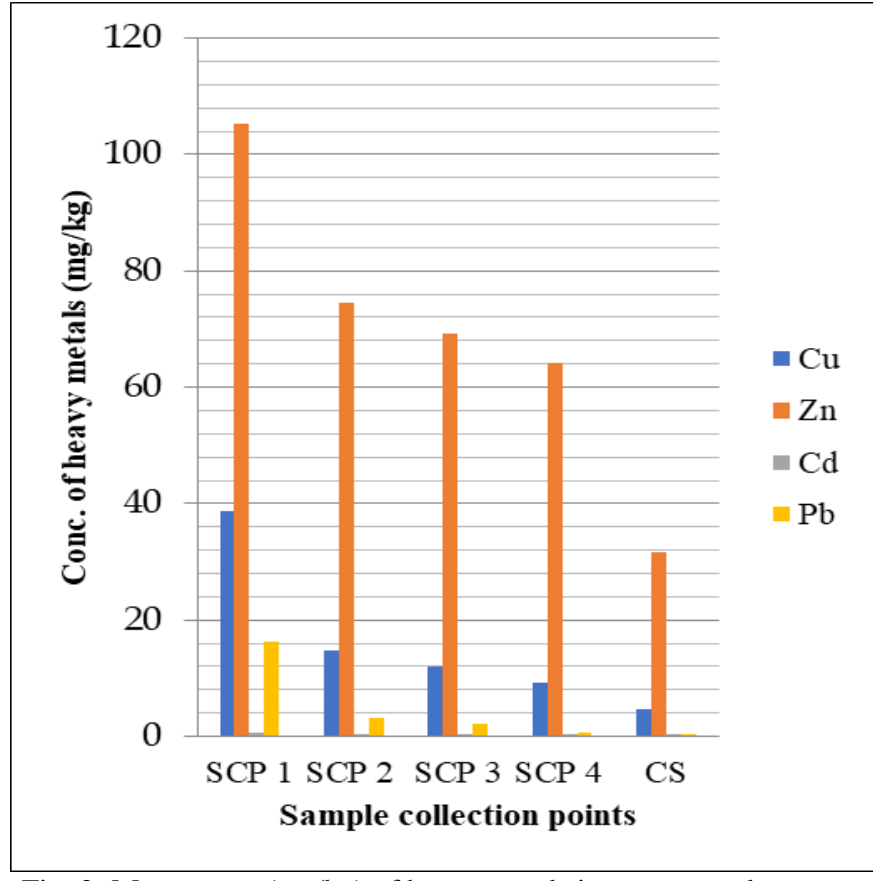

Fig. 2: Mean conc. (mg/kg) of heavy metals in grass samples across the sampling points; $\mathrm{CS}=$ Control Site

For the analysed metals in invertebrate (Stag beetle) samples as shown in Figure 3, the mean concentration of $\mathrm{Cu}$ varied from $11.3 \mathrm{mg} / \mathrm{kg} ; 64.5 \mathrm{mg} / \mathrm{kg} ; 105.3 \mathrm{mg} / \mathrm{kg} ; 9.6 \mathrm{mg} / \mathrm{kg}$ with CS value of $108.1 \mathrm{mg} / \mathrm{kg}$. The level of $\mathrm{Zn}$ ranged from $134.1 \mathrm{mg} / \mathrm{kg}$; $297.2 \mathrm{mg} / \mathrm{kg} ; 209.4 \mathrm{mg} / \mathrm{kg}$ and $152.8 \mathrm{mg} / \mathrm{kg}$ while the value at the CS was $492.9 \mathrm{mg} / \mathrm{kg}$. The mean level for $\mathrm{Cd}$ ranged from $0.91 \mathrm{mg} / \mathrm{kg} ; 1.41 \mathrm{mg} / \mathrm{kg} ; 3.78 \mathrm{mg} / \mathrm{kg}$ and $0.63 \mathrm{mg} / \mathrm{kg}$ with CS of $0.45 \mathrm{mg} / \mathrm{kg}$. Lastly, the level of $\mathrm{Pb}$ varied from $15.9 \mathrm{mg} / \mathrm{kg}$; $11.4 \mathrm{mg} / \mathrm{kg} ; 29.1 \mathrm{mg} / \mathrm{kg}$ and $8.0 \mathrm{mg} / \mathrm{kg}$ with the CS value of $0.53 \mathrm{mg} / \mathrm{kg}$; all respectively at SCP1, SCP2, SCP3 and SCP4 across the sampling periods.

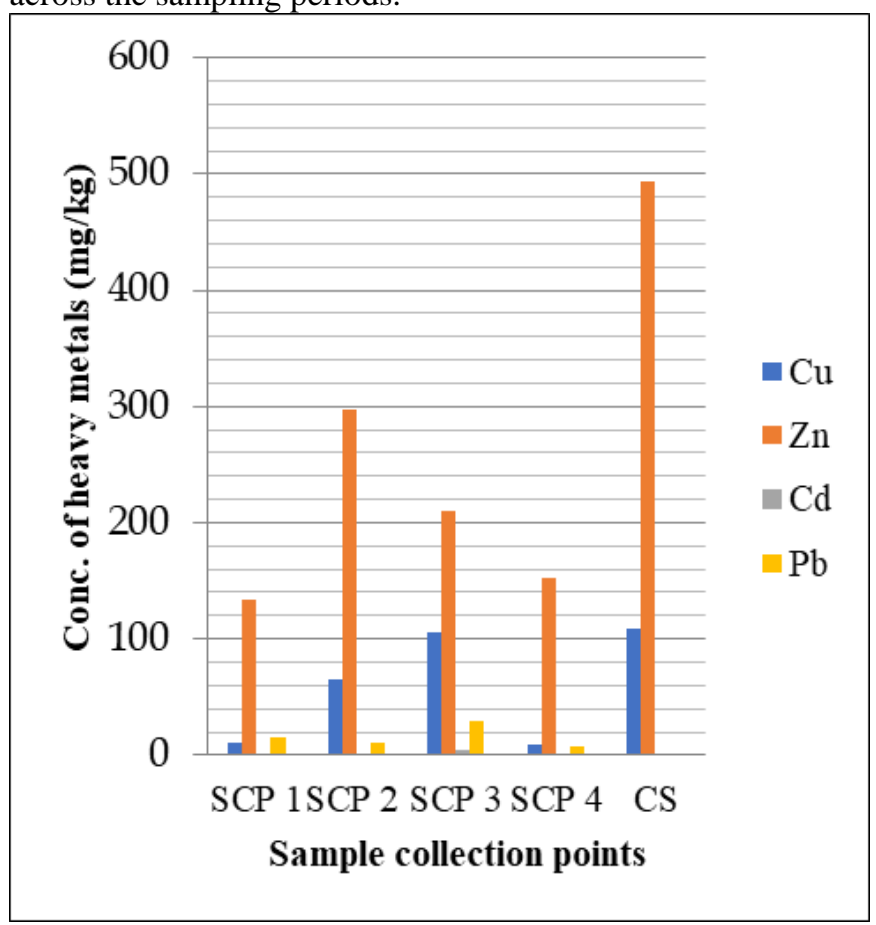

Fig 3: Mean conc. (mg/kg) of heavy metals in insect (Stag beetle) across the sampling points; $\mathrm{CS}=$ Control Site.
The calculated transfer factor (TF) for the heavy metals (Table 1) were in the range of 0.02-0.31 (Cu); 0.05-1.16 $(\mathrm{Zn})$; 0.11-0.58 $(\mathrm{Cd})$ and $0.03-0.12(\mathrm{~Pb})$ across SCP1 to SCP4 respectively.

TABLE I: HEAVY METALS TRANSFER FACTORS (TFS) ACROSS SAMPLE COLLECTION POINTS

\begin{tabular}{|c|c|c|c|c|}
\hline SCPs & \multicolumn{4}{|c|}{ Trace Metals } \\
\hline & $\mathrm{Cu}$ & $\mathrm{Zn}$ & $\mathrm{Cd}$ & $\mathrm{Pb}$ \\
\hline SCP 1 & 0.02 & 0.05 & 0.58 & 0.12 \\
\hline SCP 2 & 0.11 & $0.75^{*}$ & 0.11 & 0.05 \\
\hline SCP 3 & 0.31 & $1.16^{*}$ & 0.16 & 0.10 \\
\hline SCP 4 & 0.18 & $0.96^{*}$ & 0.15 & 0.03 \\
\hline
\end{tabular}

* Values closer to or $>1$

The Metal Pollution Indices (MPIs) of analysed heavy metals are as shown in shown Table 2 below.

TABLE II: METAL POLLUTION/CONTAMINATION INDICES (MPIS) AND POLLUTION SIGNIFICANCE ACROSS SAMPLING SITES

\begin{tabular}{|c|c|c|c|c|}
\hline SCPs & \multicolumn{4}{|c|}{ Heavy metals } \\
\hline & $\mathbf{C u}$ & $\mathbf{Z n}$ & Cd & $\mathbf{P b}$ \\
\hline SCP 1 & $\begin{array}{l}\mathbf{1 5 . 6}(\mathbf{8 . 1}- \\
\mathbf{1 6 . 0}) \\
\text { Very severe } \\
\text { pollution } \\
\text { (VSP) }\end{array}$ & $\begin{array}{l}\mathbf{2 2 . 1}(>16) \\
\text { Excessive } \\
\text { pollution } \\
(\mathrm{EP})\end{array}$ & $\begin{array}{l}3.80(2.1 \\
-4.0) \\
\text { Moderate } \\
\text { pollution } \\
(\mathrm{MP})\end{array}$ & $\begin{array}{l}\mathbf{1 1 7 . 4} \\
(>16) \\
\text { Excessive } \\
\text { pollution } \\
(\mathrm{EP})\end{array}$ \\
\hline SCP 2 & $\begin{array}{l}0.83(0.76- \\
1.0) \\
\text { Very severe } \\
\text { contam. } \\
\text { (VSC) }\end{array}$ & $\begin{array}{l}1.10 \\
(1.1-2.0) \\
\text { Slight } \\
\text { pollution } \\
(\mathrm{SP})\end{array}$ & $\begin{array}{l}0.74 \\
(0.5-0.75) \\
\text { Severe } \\
\text { contam. } \\
(\mathrm{SC})\end{array}$ & $\begin{array}{l}\mathbf{5 1 . 7}(>\mathbf{1 6}) \\
\text { Excessive } \\
\text { pollution } \\
(\mathrm{EP})\end{array}$ \\
\hline SCP 3 & $\begin{array}{l}0.24 \\
(0.1-0.25) \\
\text { Slight } \\
\text { Contam. } \\
(\mathrm{SC})\end{array}$ & $\begin{array}{l}0.65 \\
(0.5-0.75) \\
\text { Severe } \\
\text { contam. } \\
(\mathrm{SC}) \\
\end{array}$ & $\begin{array}{l}0.32 \\
(0.26-0.5) \\
\text { Moderate } \\
\text { contam. } \\
(\mathrm{MC}) \\
\end{array}$ & $\begin{array}{l}\mathbf{1 8 . 1}(>\mathbf{1 6}) \\
\text { Excessive } \\
\text { pollution } \\
(\mathrm{EP})\end{array}$ \\
\hline SCP 4 & $\begin{array}{l}0.33 \\
(0.26-0.5) \\
\text { Moderate } \\
\text { contam } \\
(\mathrm{MC}) \\
\end{array}$ & $\begin{array}{l}0.73 \\
(0.5-0.75) \\
\text { Severe } \\
\text { contam } \\
(\mathrm{SC})\end{array}$ & $\begin{array}{l}0.33 \\
(0.26-0.5) \\
\text { Moderate } \\
\text { contam } \\
(\mathrm{MC})\end{array}$ & $\begin{array}{l}\mathbf{1 6 . 3}(>\mathbf{1 6}) \\
\text { Excessive } \\
\text { pollution } \\
(\mathrm{EP})\end{array}$ \\
\hline
\end{tabular}

Significance adapted from [32], bold values are those that are of environmental and human concern

From Table 2, the metallic range obtained were $\mathrm{Cu}$ (0.24-15.6); $\mathrm{Zn}$ (0.65-22.1); $\mathrm{Cd}$ (0.32-3.80) and $\mathrm{Pb}$ (16.3-117.4). These ranges will shed more light into the extent of contamination of analysed metals at the sample collection sites. It is also imperative to investigate possible relationship between the analysed metals at the various sample collection points (SCPs). At SCP1, near perfect correlation $(r=0.999)$ were obtained between the analysed metals while at SCP2 the correlation between the metals varied from -0.170 to 0.992 . At $\mathrm{SCP} 3$ the metal correlation spectrum was from 0.67- 0.99 while at SCP4, the correlation varied from -0.47 to 0.98 . 
TABLE III. CORRELATION ANALYSIS BETWEEN ANALYSED METALS IN SAMPLES

\begin{tabular}{|l|l|l|l|l|l|}
\hline $\boldsymbol{S} \boldsymbol{C P} \boldsymbol{s}$ & & $\boldsymbol{C u}$ & $\boldsymbol{Z n}$ & $\boldsymbol{C d}$ & $\boldsymbol{P b}$ \\
\hline & $\boldsymbol{C} \boldsymbol{u}$ & 1 & & & \\
\hline & $\boldsymbol{Z n}$ & 0.999 & 1 & & \\
\hline 1 & $\boldsymbol{C} \boldsymbol{d}$ & 0.999 & 0.999 & 1 & \\
\hline & $\boldsymbol{P} \boldsymbol{b}$ & 0.999 & 0.999 & 0.999 & 1 \\
\hline & & & & & \\
\hline & $\boldsymbol{C} \boldsymbol{u}$ & 1 & & & \\
\hline 2 & $\boldsymbol{Z n}$ & 0.006 & 1 & & \\
\hline & $\boldsymbol{C} \boldsymbol{d}$ & 0.984 & -0.169 & 1 & \\
\hline & $\boldsymbol{P} \boldsymbol{b}$ & 0.956 & -0.287 & 0.993 & 1 \\
\hline & & & & & \\
\hline & $\boldsymbol{C u}$ & 1 & & & \\
\hline 3 & $\boldsymbol{Z n}$ & 0.942 & 1 & & \\
\hline & $\boldsymbol{C} \boldsymbol{d}$ & 0.987 & 0.875 & 1 & \\
\hline & $\boldsymbol{P} \boldsymbol{b}$ & 0.880 & 0.671 & 0.946 & 1 \\
\hline & & & & & \\
\hline & $\boldsymbol{C} \boldsymbol{u}$ & 1 & & & \\
\hline 4 & $\mathbf{Z n}$ & -0.471 & 1 & & \\
\hline & $\boldsymbol{C d}$ & 0.979 & -0.282 & 1 & \\
\hline & $\boldsymbol{P b}$ & 0.924 & -0.097 & 0.982 & 1 \\
\hline
\end{tabular}

\section{SCP = Sample Collection Point}

\section{DISCUSSION}

The focus of the study was to assess the prevalence of heavy metals of toxicological potential in soil and to examine possible mobility or transfer of these metals to some living organisms whose sustenance hinged on this ecosystem. Heavy metals exist naturally in the earth's crust however, anthropogenic activities have exacerbated their level [25]. Highest mean value of 2533 $\mathrm{mg} / \mathrm{kg} ; 2020.1 \mathrm{mg} / \mathrm{kg} ; 21.3 \mathrm{mg} / \mathrm{kg}$ and $140 \mathrm{mg} / \mathrm{kg}$, all at SCP1 were obtained for $\mathrm{Cu}, \mathrm{Zn}, \mathrm{Cd}$ and $\mathrm{Pb}$ respectively in soil samples which were significantly higher (in the order of magnitude of 16, 20, 4 and 117 respectively) than the mean values obtained at control sites (CS) for these metals. They were also higher than the maximum permissible limits (MPLs) of $50-140 \mathrm{mg} / \mathrm{kg}$ of Cu; $150-300 \mathrm{mg} / \mathrm{kg}$ of Zn; $1-3 \mathrm{mg} / \mathrm{kg}$ of Cd except for $50-300 \mathrm{mg} / \mathrm{kg}$ of $\mathrm{Pb}$ in soil [26]. This outcome confirmed the notion of soil as a sink for heavy metals.

It is generally known that some living organisms depend on the soil for either sustenance, habitation, or both. Hence, this study revealed the mobility of the metals from the soil to plants and lower animal because of their interaction with the soil ecosystem as shown in Figures 4 -7.

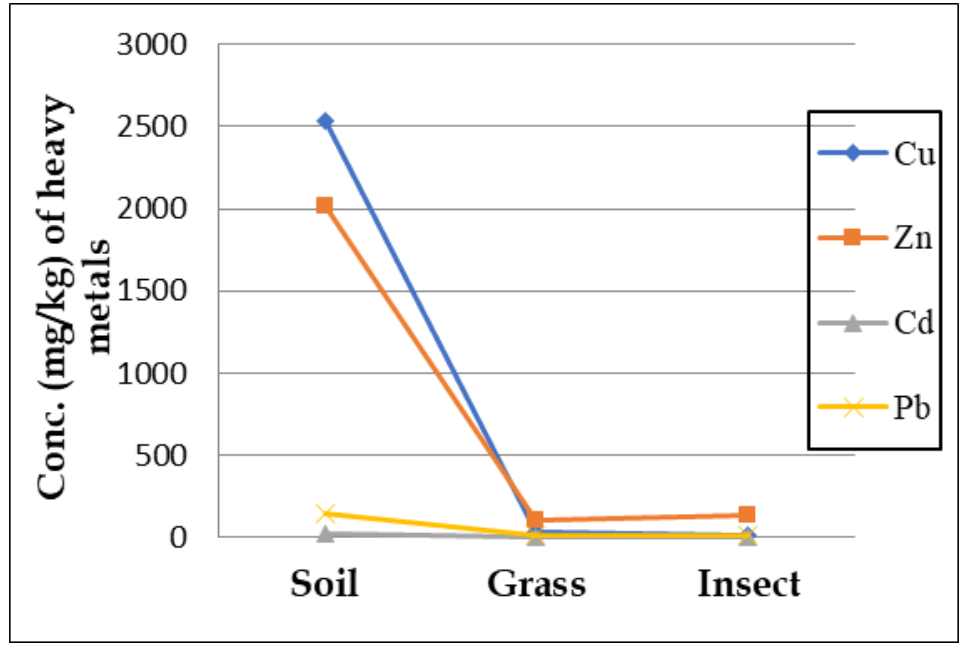

Fig 4: Mean conc. trend of heavy metals $(\mathrm{mg} / \mathrm{kg})$ in all samples at sample collection point 1 (SCP1)

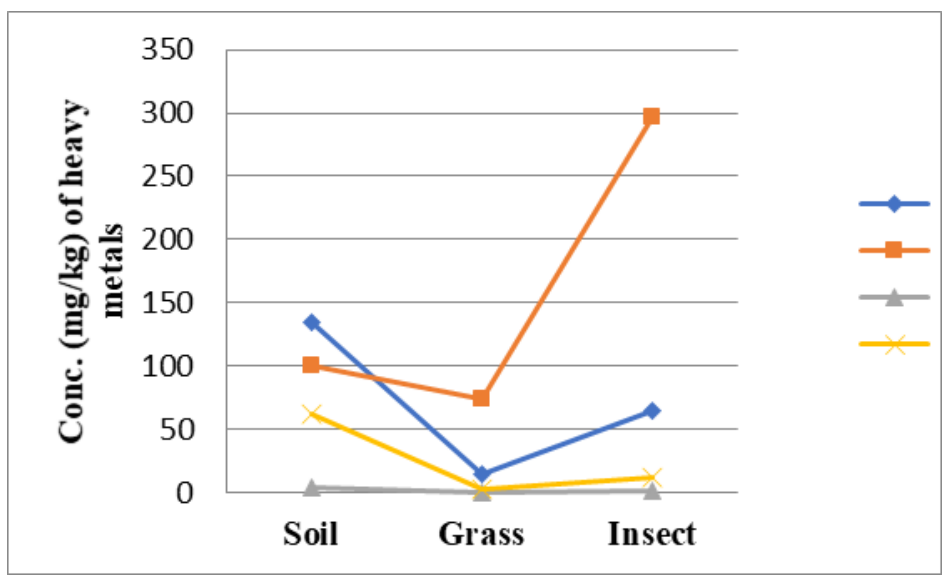

Fig 5: Mean conc. $(\mathrm{mg} / \mathrm{kg})$ trend of heavy metals in samples at sample collection point 2 (SCP2)

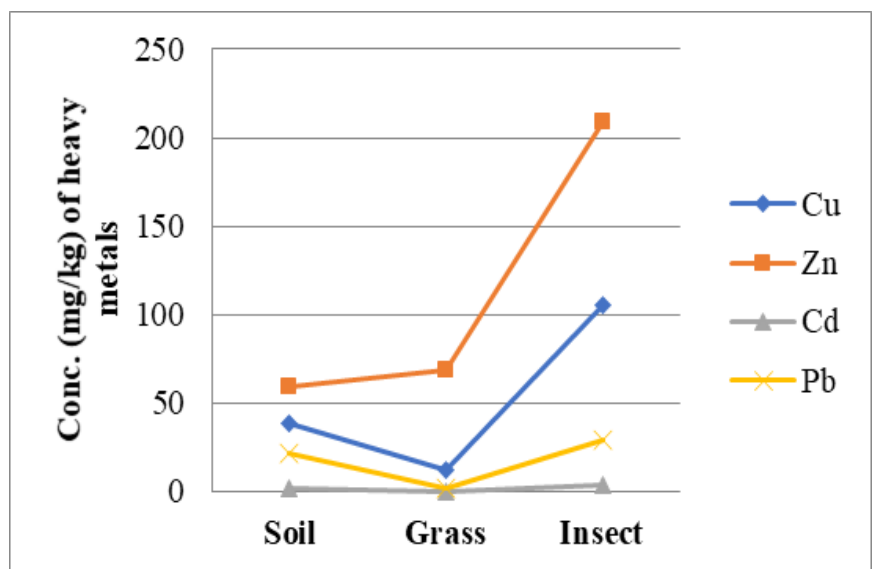

Fig 6: Mean conc. (mg/kg) trend of heavy metals in samples at sample collection point 3 (SCP3) 


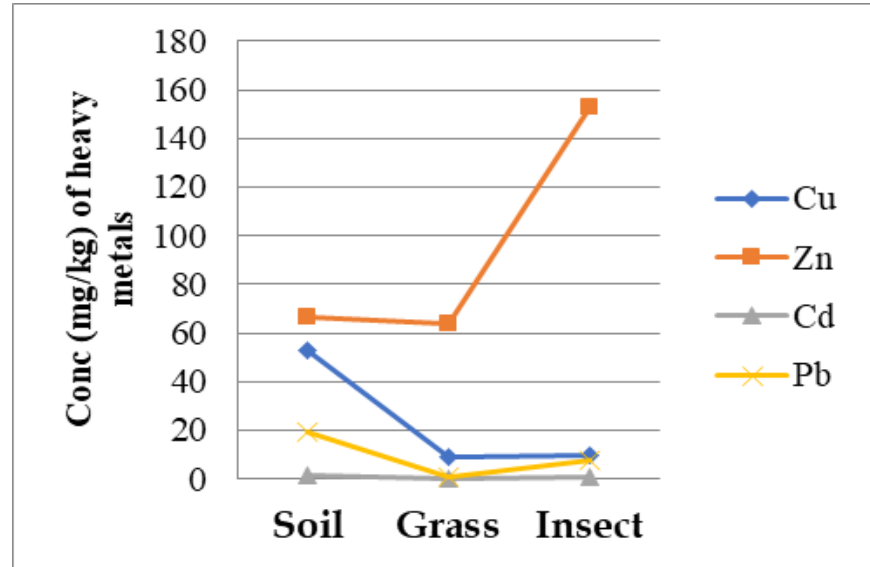

Fig 7: Mean conc. $(\mathrm{mg} / \mathrm{kg})$ trend of heavy metals in samples at sample collection point 4 (SCP4)

Possible accumulation of some of these metals can be observed with higher level of $\mathrm{Zn}$ in the lower animal at SCP2 (Figure 5); $\mathrm{Zn}$ and $\mathrm{Cu}$ at SCP3 (Figure 6) and $\mathrm{Zn}$ at SCP4 (Figure 7). The level of heavy metals obtained in plant samples was generally lower than those in soil and the insect. The plant's accumulating capacity was relatively lower when compared to similar study where higher accumulation tendency was reported [27]. The low accumulation may also be because or influence of soil conditions such as conductivity and $\mathrm{pH}$ [28]. The highest mean level of $\mathrm{Cu}$ obtained in plant samples was lower $(0.38 \mathrm{mg} / \mathrm{kg})$ than the maximum allowable limit (MAL) of $73 \mathrm{mg} / \mathrm{kg}$ of Cu in plants while those recorded by $\mathrm{Zn}$, $100 \mathrm{mg} / \mathrm{kg}$; $\mathrm{Cd}, 0.1 \mathrm{mg} / \mathrm{kg}$ and $\mathrm{Pb}, 0.3 \mathrm{mg} / \mathrm{kg}$ were higher than the recommended values [24]. Although, there were no standard of limits for metals in invertebrates, the detection of higher levels of $\mathrm{Zn}$ (Figure 5, SCP2), $\mathrm{Cu}$ and $\mathrm{Zn}$ (Figure 6, SCP3) and Zn (Figure 7, SCP4) relative to other samples were indication of migration and high pollution of the ecosystem. Accumulation of heavy metals in insect species relative to the soil has been reported [29]. Higher levels of $\mathrm{Pb}(1,243 \mathrm{mg} / \mathrm{kg})$ and $\mathrm{Cd}(575.6 \mathrm{mg} / \mathrm{kg})$ in insect have also been reported in a previous study [30].

\section{A. Metal Transfer Factor (TF), Metal Pollution Indices (MPIs) and ANOVA}

Metal transfer factor, as expressed by the soil-to-plant transfer is one of the key components of human exposure to heavy metals through the food chain. The accumulation of heavy metals in plants predisposes their transfer to ruminants and eventually to human. Transfer factor value close to or greater than 1 is an indicative of high transfer/accumulation of metals by the plant. In this study, moderate TF values of 0.75 (SCP2); high TF of 1.16 (SCP3) and 0.96 (SCP 4) were obtained for Zn while an average TF value of 0.58 at SCP1 was obtained for $\mathrm{Cd}$ as shown in Table 1. High TF values of $1.11(\mathrm{Cd})$ and $0.89(\mathrm{~Pb})$ have also been reported in a similar study [31]. Generally, these high TFs are quite worrisome in view of the health implications across the food chain.

Elevated levels of toxic heavy metals in the environment have been linked to anthropogenic activities. Hence, Metal pollution indices (MPIs) are usually determined to establish this veracity. The MPI standard ranges and their significances, adapted from [32] together with values obtained in this study are as presented in Table 2. Of great concern were the very severe pollution index of 15.6 within the range of $(8.1-16.0)$ for $\mathrm{Cu}$; excessive pollution index of 22.1 for $\mathrm{Zn}(>16)$ at SCP1 and excessive pollution for $\mathrm{Pb}(>16)$ for SCP1 to SCP4. These are indicative of anthropogenic input of the heavy metals into the environment.

The heavy metals correlation analysis revealed near perfect correlation $(r=0.999)$ between all analysed metals at SCP1; very strong correlation between $\mathrm{Cu}$ and $\mathrm{Cd}(\mathrm{r}=0.98)$ and $\mathrm{Cu}$ and $\mathrm{Pb}(0.95)$ as well as $\mathrm{Cd}$ and $\mathrm{Pb}(\mathrm{r}=0.99)$ at SCP2. At SCP3, strong correlation was also observed between $\mathrm{Cu}$ and $\mathrm{Zn}$ (0.94); $\mathrm{Cu}$ and $\mathrm{Cd}(0.99)$ as well as $\mathrm{Cd}$ and $\mathrm{Pb}$ with $(\mathrm{r}=0.95)$. The correlation between $\mathrm{Cu}$ and $\mathrm{Cd}(\mathrm{r}=0.98) ; \mathrm{Cu}$ and $\mathrm{Pb}(\mathrm{r}=0.92)$ and $\mathrm{Cd}$ and $\mathrm{Pb}(\mathrm{r}=0.98)$ were considered very strong. All these are indicative of strong association and interaction between these metals as shown in Table 4. However, $\mathrm{Zn}$ and $\mathrm{Cd}(\mathrm{r}=-$ $0.17)$ and $\mathrm{Zn}$ and $\mathrm{Pb}(\mathrm{r}=-0.29)$ at SCP2 were found to be negatively correlated.

\section{CONCLUSION}

The prevalence of analysed toxic heavy metals in soil was revealed in the study as well as possible migration or transfer to environmental indicators such as plant and lower invertebrate organism (insect) within the soil ecosystem. The outcome confirmed the prevalence of analysed metals above permissible levels. This can be associated mostly with anthropogenic activities such as mining, quarry of rocks with metal impurities, petrochemical industries that are taking place in the locality. The mobility of trace metals from soil to plant and the insect was established through TF values of 1.0 and above obtained for some of the analysed metals. This is quite worrisome in that possible bio-magnification across the food chain is highly possible resulting in exposure and threat to human health.

\section{REFERENCES}

[1] R. Singh, N. Gautam, A. Mishra, and R. Gupta, "Heavy metals and living systems: An overview”, India J Pharmacol., vol. 43, no. 3, pp. 246-253, 2011. https://doi.org/10.4103/0253-7613.81505

[2] F.A. Armah, R. Quansah, and I. Luginaah, "A Systematic Review of Heavy Metals of Anthropogenic Origin in Environmental Media and Biota in the Context of Gold Mining in Ghana", International Scholarly Research Notices, pp. 1-37, 2014.

[3] J. Marrugo-Negrete, J. Pinedo-Hernandez, and S. Dez, “Assessment of heavy metal pollution, spatial distribution and origin in agricultural soils along the Sinu River Basin, Colombia", Environ Res, vol. 154, pp. 380-8, 2017 https://doi.org/10.1016/j.envres.2017.01.021

[4] F.M. Adebiyi, and M.O Afedia, "The Ecological Impact of Used Petrochemical Oils on Soil Properties with Special Reference to Physicochemical and Total Petroleum Hydrocarbon Contents of Soils around Automobile Repair Workshops" Energy Sources, Part A: Recovery, Utilization and Environmental Effects, vol. 33, No. 16, pp.1556-1565, 2011. https://doi.org/10.1080/15567030903397883

[5] S. Fan, and X. Wang, "Analysis and assessment of heavy metals pollution in soils around $\mathrm{a} \mathrm{Pb}$ and $\mathrm{Zn}$ smelter in Baoji City, Northwest China", Human and Ecological Risk Assessment: An Int. J, vol. 23, No. 5, pp. 1099-1120, May 2017

[6] Naveedullah, M.Z. Hashmi, C. Yu, H. Shen, D. Duan, C. Shen, L. Lou, and Y. Chen, "Risk Assessment of Heavy Metals Pollution in Agricultural Soils of Siling Reservoir Watershed in Zhejiang Province, 
China", BioMed Research International, vol. 2013, https://doi.org/10.1155/2013/590306.

[7] M. Jaishankar, T. Tseten, N. Anbalagan, B. B. Mathew, and K.N Beeregowda, "Toxicity, mechanism and health effects of some heavy metals" Interdiscip. Toxicol., vol. 2, no. 2, pp. 60-72, 2014. https://doi.org/10.2478/intox-2014-0009

[8] A. Kartenkamp, "Are cadmium and other heavy metals compounds acting as endocrine disrupters"? Met Ions Life Sci., vol. 8, pp. 305- 317, 2011

[9] L. Cai, Z. Xu, and M. Ren, "Source identification of eight hazardous heavy metals in agricultural soils of Huizhou, Guangdong Province, China," Ecotoxicology and Environmental Safety, vol. 78, pp. 2-8, 2012. https://doi.org/10.1016/j.ecoenv.2011.07.004

[10] B.S. Gillis, I.M. Gavin, and Z. Arbieva, "Analysis of lead toxicity in human cells", BMC Genomics, vol. 13, pp. 344 https://doi.org/10.1186/1471-2164-13-344

[11] S. Issaka, and M.A. Ashraf, "Impact of soil erosion and degradation on water quality: a review", Geology, Ecology and landscapes, vol. 1, No.1, pp. 1-11, 2017

[12] S.M. Shaheen, and J. Rinklebe, "Geochemical fractions of chromium, copper, and zinc and their vertical distribution in floodplain soil profiles along the Central Elbe", Geoderma, vol. 228-229, pp. 152-159, 2014. https://doi.org/10.1016/j.geoderma.2013.10.012

[13] M.A. Kashem, and B.R. Singh, "Metal availability in contaminated soils: I. Effects of flooding and organic matter on changes in Eh, $\mathrm{pH}$ and solubility of $\mathrm{Cd}, \mathrm{Ni}$ and $\mathrm{Zn}$ ", Nutrient Cycling in Agroecosystems, vol. 61, no. 3, pp. 247-255, 2001.

[14] A. Popenda. "Effect of redox potential on heavy metals and As behaviour in dredged sediments", Desalination and Water Treatment, vol. 52, no. 19-21, pp. 3918-3927, 2014 https://doi.org/10.1080/19443994.2014.887449

[15] S. Dragovic, N. Mihailovic, B. Gajic, "Heavy metals in soils: Distribution, relationship with soil characteristics and radionuclides and multivariate assessment of contamination sources", Chemosphere, vol. 72, pp. 491-495, 2008. https://doi.org/10.1016/j.chemosphere.2008.02.063

[16] S.F. Dan, U.U. Umoh, and V.N. Osabor, "Seasonal variation of enrichment and contamination of heavy metals in the surface water of Qua Iboe River Estuary and adjoining creeks, South-South Nigeria", J of Oceanography and Marine Science, vol. 5, no. 6, pp.25-54, 2014. https://doi.org/10.5897/JOMS2013.0103

[17] A.J. Zimmerman, and D.C. Weindorf, "Heavy Metal and Trace Metal Analysis in Soil by Sequential Extraction: A Review of Procedures,"International Journal of Analytical Chemistry, doi.org/10.1155/2010/387803, Feb 2010.

[18] Q. Tu, X.-Q. Shan, J. Qian, and Z.-M. Ni, "Trace metal redistribution during extraction of model soils by acetic acid/sodium acetate," Analytical Chemistry, vol. 66, no. 21, pp. 3562-3568, 1994. https://doi.org/10.1021/ac00093a005

[19] A. Tessier, P.G.C. Campbell, and M. Blsson, "Sequential extraction procedure for the speciation of particulate trace metals," Analytical Chemistry, vol. 51, no. 7, pp. 844-851, 1979. https://doi.org/10.1021/ac50043a017

[20] S.M. Shaheen, and J. Rinklebe, "Geochemical fractions of chromium, copper, and zinc and their vertical distribution in floodplain soil profiles along the Central Elbe", Geoderma, vol. 228-229, pp. 152-159, 2014. https://doi.org/10.1016/j.geoderma.2013.10.012

[21] M.M, Nederlof, W.H. Van Riemsdijk, and F.A.M. De Haan. "Effect of $\mathrm{pH}$ on The Bioavailability of Metals in Soils". Integrated Soil and sediment Research: A basis for Proper Protection, pp.215-219.

[22] B.D. Bolzan, "Effect of $\mathrm{pH}$ and Soil Environment", World News of Natural Sciences, vol. 8, pp. 50-60, 2017.

[23] NSA, Namibia Statistics Agency, Government of the Republic of Namibia. The Namibia Population and Housing Census Report. DDI_NAM_NSA_PHC_2011_v01_PUMS, Windhoek, Namibia

[24] O.R. Awofolu, "A survey of trace metals in vegetation, soil and lower animal along some selected major roads in metropolitan city of Lagos", vol. 105, no. 1-3, pp. 431-47, 2005.

[25] P.B. Tchounwou, C.G. Yedjou, A.K. Patlolla, and D.J. Sutton, "Heavy Metals Toxicity and the Environment", EXS, vol. 101, pp. 133-164, 2012 . https://doi.org/10.1007/978-3-7643-8340-4_6

[26] EEC, European Economic Commission. European Commission Office for Official Publications of the European Communities, Luxembourg. Council Directive 86/278/ EEC on the protection of environment and of soil, when sewage sludge is used in agriculture.

[27] Y.E. Chen, S. Yuan, Y.Q. Su, and L. Wang, "Comparison of heavy metal accumulation capacity of some indigenous mosses in Southwest China cities: a case study in Chengdu City", Plant, Soil Environ., vol. 56, pp. 60-66, 2010. https://doi.org/10.17221/160/2009-PSE

[28] M. Mleczek, Z. Magdziak, I. Rissmann, and P. Golinski, "Effect of different soil conditions on selected heavy metal accumulation by Salix viminalis tissues", J Environ. Sci \& Health, Part A, vol. 44, no. 14, pp. 1609-1616, 2009.

[29] CODEX STAN 223, General standard for vegetables Codex Alimentarius Commission Joint FAO/WHO Food Standards Programme Food and Agriculture Organization of the United Nations, Rome Italy, vol. 13, 2001

[30] I. Azam, S. Afsheen, A. Zia, M. Javed, R. Saeed, M.K. Sarwar, and B Munir, "Evaluating Insects as Bioindicators of Heavy Metal Contamination and Accumulation near Industrial Area of Gujrat, Pakistan", Research International, dx.doi.org/10.1155/2015/942 751, 2015

[31] Z. Zhong-Sheng, L. Xian-Guo, W. Qi-Chao, and Z. Dong-Mei, "Mercury, Cadmium and Lead Biogeochemistry in the Soil-Plant-Insect System in Huludao City", Bull Environ Contam Toxicol., vol. 83, pp.255-259, 2009. https://doi.org/10.1007/s00128-009-9688-6

[32] H.A. Haliru, L.P. Ling, and O.S. Selaman, "Environmental Burden of Heavy Metal Contamination Levels in Soil from Sewage Irrigation Area of Geriyo Catchment, Nigeria", Civil and Environmental Research, vol. 6, no. 10 , pp. 118,2014 